\title{
GAMBARAN KEJADIAN BERAT BADAN LAHIR RENDAH MENURUT FAKTOR MATERNAL DI RSUD KABUPATEN BREBES TAHUN 2015
}

\author{
Dede Marriyah $^{1}$, Ulfatul Latifah ${ }^{2}$ \\ email: ulfatul.bidan@poltektegal.ac.id \\ ${ }^{12}$ DIII Kebidanan Politeknik Harapan Bersama \\ Jln. Mataram No. 09 Tegal \\ Telp Fax (0283)352000
}

\begin{abstract}
Abstrak
Angka Kematian Bayi (AKB) merupakan indikator pertama dalam menentukan derajat kesehatan anak. Bayi dengan berat badan lahir rendah (BBLR) merupakan salah satu faktor risiko yang mempunyai kontribusi terhadap kematian bayi khususnya pada masa perinatal. Kematian perinatal pada BBLR adalah 8 kali lebih besar dari bayi normal. Di RSUD Kabupaten Brebes kasus BBLR menunjukkan hasil yang tinggi yaitu pada tahun 2012 sebanyak 481 orang, tahun 2013 sebanyak 392 orang, dan tahun 2014 sebanyak 180 orang. Penelitian ini bertujuan untuk mengetahui gambaran distribusi kejadian berat badan lahir rendah (BBLR) menurut faktor maternal di RSUD Kabupaten Brebes. Penelitian ini dilakukan menggunakan metode survey deskriptif kepada 20 orang ibu yang melahirkan di RSUD Kabupaten Brebes dengan kriteria inklusi dan ekslusi yang sudah ditentukan. Hasil penelitian ini menunjukkan bahwa kejadian BBLR (20 orang) sebagian besar adalah pada ibu yang berusia antara 20-35 tahun (60\%), paritas 1 dan $\geq 4(75 \%)$, LILA $\leq 23,5 \mathrm{~cm}$ (55\%), kadar haemoglobin $<119 \%$ (70\%), tekanan darah $<140 / 90 \mathrm{mmHg}(65 \%)$. Paritas, KEK, dan anemia berisiko terhadap BBLR sehingga perlunya mengadakan penyuluhan pada ibu hamil mengenai risiko BBLR dan dampak yang ditimbulkan akibat BBLR dan pemantauan status gizi ibu sebelum dan selama hamil perlu dilakukan sehingga kejadian BBLR dapat diturunkan terutama di Kabupaten Brebes.
\end{abstract}

Kata kunci: Faktor Maternal, BBLR

\section{Pendahuluan}

Bayi berat badan lahir rendah (BBLR) adalah bayi yang lahir dengan berat badan kurang dari 2.500 gram tanpa memandang masa kehamilan. Bayi dengan berat badan lahir rendah (BBLR) merupakan salah satu faktor risiko yang mempunyai kontribusi terhadap kematian bayi khususnya pada masa perinatal. Kematian perinatal pada Bayi BBLR adalah 8 kali lebih besar dari bayi normal. Prognosis akan lebih buruk bila berat badan semakin rendah, kematian akan sering disebabkan karena komplikasi neonatal seperti asfiksia, aspirasi, pneumonia, perdarahan intra kranial, hipoglikemia Selain itu bayi BBLR dapat mengalami gangguan mental dan fisik pada usia tumbuh kembang selanjutnya, sehingga membutuhkan biaya perawatan yang tinggi. Bayi dengan berat badan lahir rendah ( BBLR ) hingga saat ini masih merupakan masalah di seluruh dunia karena merupakan penyebab kesakitan dan kematian pada masa bayi baru lahir ${ }^{[1]}$
Faktor-faktor yang mempengaruhi kejadian berat badan lahir rendah (BBLR) yaitu faktor ibu seperti gizi saat hamil yang kurang, usia ibu, paritas ibu, penyakit menahun ibu (hipertensi, jantung, gangguan pembuluh darah), faktor kehamilan seperti hamil dengan hidramnion, hamil kembar, perdarahan antepartum, komplikasi hamil (pre-eklamsia/eklamsia, ketuban pecah dini), faktor janin seperti cacat bawaan, infeksi dalam rahim, dan faktor yang masih belum diketahui ${ }^{[2]}$.

Prevalensi berat badan lahir rendah (BBLR) diperkirakan $15 \%$ dari seluruh kelahiran di dunia dan lebih sering terjadi di negara-negara berkembang dan angka kematiannya 35 kali lebih tinggi dibanding pada bayi dengan berat lahir lebih dari 2500 $\operatorname{gram}^{[3]}$.

Di RSUD Kabupaten Brebes kasus BBLR menunjukkan hasil yang tinggi yaitu pada tahun 2012 sebanyak 481 orang, tahun 2013 sebanyak 392 orang, dan tahun 2014 
sebanyak 180 orang. Kasus BBLR di RSUD Brebes merupakan penyebab utama kematian pada bayi baru lahir.

Menurut WHO 17\% dari 25 juta persalinan pertahun adalah bayi berat lahir rendah dan hampir semua terjadi di negara berkembang. Kejadian berat badan lahir rendah (BBLR) yang tinggi menunjukkan bahwa kualitas kesehatan dan kesejahteraan masyarakat itu masih rendah, untuk itu diperlukan upaya untuk menurunkan angka kejadian BBLR, agar kualitas kesehatan dan kesejahteraan menjadi meningkat. Kejadian BBLR ini bisa dicegah bila kita mengetahui faktor-faktor penyebabnya. Penelitian ini bertujuan untuk mengetahui gambaran distribusi kejadian berat badan lahir rendah (BBLR) menurut faktor maternal di RSUD Kabupaten Brebes ${ }^{[4]}$.

\section{Metode Penelitian}

Penelitian menggunakan metode survey deskriptif dengan melihat gambaran pendistribusian kejadian berat badan lahir rendah (BBLR) menurut faktor maternal di RSUD Kabupaten Brebes. Kriteria sampel pada penelitian ini adalah ibu yang melahirkan di RSUD Kabupaten Brebes, ibu yang melahirkan dengan umur kehamilan 37-42 minggu (aterm), ibu yang melahirkan dengan berat badan bayi $<2.500$ gram. Kriteria eksklusi sampel antara lain ibu melahirkan anak kembar (gemeli), ibu yang melahirkan dengan adanya kelainan kongenital, ibu melahirkan dengan bayi lahir meninggal dan didapatkan sampel sebanyak 20 orang.

Penelitian dilakukan dengan wawancara dan melihat buku KIA yang kemudian data dilakukan analisis menggunakan analisis deskriptif.

\section{Hasil dan Pembahasan}

Penelitian dilakukan pada 20 orang ibu yang melahirkan di RSUD Kabupaten Brebes yang memenuhi kriteria yang sudah ditentukan berupa analisa univariat untuk mengetahui deskripsi kejadian berat badan lahir rendah (BBLR) menurut faktor maternal.

Tabel 1. Distribusi frekuensi kejadian berat badan lahir rendah (BBLR) menurut faktor maternal di RSUD Kabupaten

Brebes tahun 2015.

\begin{tabular}{|c|c|c|c|c|}
\hline No & Variabel & & $\begin{array}{c}\text { Freku } \\
\text { ensi }\end{array}$ & $\begin{array}{c}\text { Prosent } \\
\text { ase }\end{array}$ \\
\hline \multirow[t]{3}{*}{1} & Umur & $<20,>3$ & 8 & $40 \%$ \\
\hline & & 5 tahun & & \\
\hline & & $\begin{array}{l}20-35 \\
\text { tahun }\end{array}$ & 12 & $60 \%$ \\
\hline \multirow[t]{2}{*}{2} & Paritas & $1, \geq 4$ & 15 & $75 \%$ \\
\hline & & $2-3$ & 5 & $25 \%$ \\
\hline \multirow[t]{2}{*}{3} & LILA & $\leq 23,5$ & 11 & $55 \%$ \\
\hline & & $\begin{array}{c}\mathrm{cm} \\
>23,5 \\
\mathrm{~cm}\end{array}$ & 9 & $45 \%$ \\
\hline \multirow[t]{5}{*}{4} & Kadar & $<7 \mathrm{~g} \%$ & 0 & $0 \%$ \\
\hline & & $7-8 \mathrm{~g} \%$ & 0 & $0 \%$ \\
\hline & & $9-10$ & 14 & $70 \%$ \\
\hline & & $\mathrm{g} \%$ & & \\
\hline & & $11 \mathrm{~g} \%$ & 6 & $30 \%$ \\
\hline \multirow[t]{3}{*}{5} & Penyakit & $\geq 140 / 90$ & 7 & $35 \%$ \\
\hline & Hipertensi & $\mathrm{mmHg}$ & & \\
\hline & & $\begin{array}{c}<140 \\
\mathrm{mmHg}\end{array}$ & 13 & $65 \%$ \\
\hline
\end{tabular}

Berdasarkan tabel 1 menunjukkan bahwa ibu yang melahirkan bayi dengan berat badan lahir rendah (BBLR) berdasarkan faktor maternal sebagian besar adalah pada ibu yang berusia antara 20-35 tahun (60\%), paritas 1 dan $\geq 4$ (75\%), LILA $\leq 23,5 \mathrm{~cm}(55 \%)$, kadar haemoglobin $<11$ $9 \%$ (70\%), tekanan darah $<140 / 90 \mathrm{mmHg}$ (65\%). usia 20-35 tahun sebanyak 12 orang $(60 \%)$, dan 8 orang $(40 \%)$ pada usia $<20$ tahun dan $>35$ tahun.

a. Usia Ibu

Walaupun secara statistik, hasil penelitian ini menunjukkan bahwa usia ibu $<20$ dan $>35$ tahun tidak berisiko terhadap kejadian berat badan lahir rendah (BBLR), namun ibu yang melahirkan pada usia berisiko tersebut harus tetap dihindari, karena kehamilan pada usia muda merupakan faktor risiko hal ini disebabkan belum matangnya organ reproduksi untuk hamil, sehingga dapat merugikan kesehatan ibu maupun perkembangan dan pertumbuhan janin yang memudahkan terjadinya BBLR $^{[2]}$, sedangkan pada umur diatas 35 tahun meskipun mereka telah berpengalaman, tetapi kondisi badannya serta kesehatannya sudah mulai menurun 
sehingga dapat mempengaruhi janin intra uterin dan dapat menyebabkan kelahiran BBLR, dimana angka kejadian tertinggi BBLR adalah pada wanita yang berusia dibawah 20 tahun dan lebih dari 35 tahun, angka kejadian terendah pada usia 20-35 tahun $^{[5]}$.

Hasil penelitian ini sejalan dengan penelitian yang dilakukan oleh Karlina (2014) yang menunjukkan bahwa usia ibu tidak berisiko terhadap kejadian berat badan lahir rendah (BBLR). Namun hasil penelitian ini tidak sejalan dengan hasil penelitian yang dilakukan oleh Colti (2008) yang menunjukkan bahwa usia ibu berisiko untuk melahirkan berat badan lahir rendah (BBLR).

\section{b. Paritas Ibu}

Ibu dengan paritas 1 dan $\geq 4$ berisiko melahirkan BBLR, pada primi terkait dengan belum siapnya fungsi organ dalam menjaga kehamilan dan menerima keadaan janin, keterampilan ibu untuk melaksanakan perawatan diri dan bayinya serta faktor psikologis ibu yang masih belum stabil, sedangkan ibu yang pernah melahirkan anak empat kali atau lebih karena paritas yang terlalu tinggi akan mengakibatkan terganggunya uterus terutama dalam hal fungsi pembuluh darah. Kehamilan yang berulang-ulang akan menyebabkan kerusakan pada dinding pembuluh darah uterus, hal ini akan mempengaruhi nutrisi ke janin pada kehamilan selanjutnya sehingga dapat menyebabkan gangguan pertumbuhan yang selanjutnya akan melahirkan bayi dengan BBLR $^{[4]}$. Hasil penelitian ini tidak sejalan dengan penelitian yang dilakukan oleh Colti (2008) yang menunjukkan bahwa paritas tidak berisiko menyebabkan berat badan lahir rendah (BBLR).

\section{c. LILA (Lingkar Lengan Atas) Ibu}

Mekanisme terjadinya BBLR akibat Kekurangan Energi Kronik (KEK) pada ibu hamil yaitu diawali dengan ibu hamil yang yang menderita KEK yang menyebabkan volume darah dalam tubuh ibu menurun dan cardiac output ibu hamil tidak cukup, sehingga menyebabkan adanya penurunan aliran darah ke plasenta. Menurunnya aliran darah ke plasenta menyebabkan dua hal yaitu berkurangnya transfer zat-zat makanan dari ibu ke plasenta yang dapat menyebabkan retardasi pertumbuhan janin dan pertumbuhan plasenta lebih kecil yang menyebabkan bayi dengan berat badan lahir rendah (BBLR) ${ }^{[7]}$.

Hasil penelitian ini sejalan dengan penelitian yang dilakukan oleh Menita (2010) yang menunjukkan KEK berisiko menyebabkan berat badan lahir rendah (BBLR). Selain itu, penelitian yang dilakukan oleh Karlina (2014) juga menunjukkan bahwa KEK berisiko menyebabkan berat badan lahir rendah (BBLR) dibandingkan dengan ibu yang tidak mengalami KEK.

\section{d. Kadar Haemoglobin Ibu}

Anemia defisiensi zat besi merupakan salah satu gangguan yang paling sering terjadi selama kehamilan. Kekurangan zat besi dapat menimbulkan gangguan atau hambatan pada pertumbuhan janin baik sel tubuh maupun sel otak. Anemia gizi dapat mengakibatkan kematian janin didalam kandungan, abortus, cacat bawaan, BBLR, anemia pada bayi yang dilahirkan. Pada ibu hamil yang menderita anemia berat dapat meningkatkan risiko morbiditas maupun mortalitas ibu dan bayi, kemungkinan melahirkan bayi BBLR dan prematur juga lebih besar $^{[3]}$.

Sebagian besar penyebab anemia pada ibu hamil adalah kekurangan zat besi yang diperlukan untuk pembentukan haemoglobin. Anemia gizi besi terjadi karena tidak cukupnya zat gizi besi yang diserap dari makanan sehari-hari guna pembentukkan sel darah merah sehingga menyebabkan ketidakseimbangan antara pemasukan dan pengeluaran zat besi dalam tubuh. Hal ini dapat menyebabkan distribusi oksigen ke jaringan akan berkurang yang akan menurunkan metabolisme jaringan sehingga pertumbuhan janin akan terhambat, dan berakibat berat badan bayi lahir rendah ${ }^{[7]}$.

Hasil penelitian ini sejalan dengan penelitian yang dilakukan oleh Karlina 
(2014) yang menunjukkan bahwa anemia berisiko menyebabkan berat badan lahir rendah (BBLR).

\section{e. Penyakit Hipertensi Ibu}

Walaupun secara statistik, hasil penelitian ini menunjukkan bahwa ibu penyakit hipertensi tahun tidak berisiko terhadap kejadian berat badan lahir rendah (BBLR), namun secara biologis hipertensi dapat menyebabkan ratardasi perkembangan janin yang berujung pada berat lahir rendah. Penyakit hipertensi dalam kehamilan merupakan kelainan vaskuler yang terjadi sebelum kehamilan atau timbul dalam kehamilan atau pada permulaan persalinan, hipertensi dalam kehamilan menjadi penyebab penting dari kelahiran mati dan kematian neonatal. Ibu dengan hipertensi akan menyebabkan terjadinya insufisiensi plasenta, hipoksia sehingga pertumbuhan janin terhambat dan sering terjadi kelahiran prematur. Hipertensi pada ibu hamil merupakan gejala dini dari preeklamsi, eklampsi dan penyebab gangguan pertumbuhan janin sehingga menghasilkan berat badan lahir rendah $(\text { BBLR })^{[1] .}$

Hasil penelitian ini sejalan dengan penelitian yang dilakukan Karlina (2014) yang menunjukkan bahwa tidak ada risiko penyakit hipertensi terhadap kejadian berat badan lahir rendah (BBLR). Namun penelitian ini tidak sejalan dengan penelitian yang dilakukan oleh Colti (2008) menyebutkan bahwa hipertensi dalam kehamilan memiliki risiko terhadap kejadian berat badan lahir rendah (BBLR).

\section{Kesimpulan}

Hasil penelitian ini menunjukkan bahwa kejadian BBLR (20 orang) sebagian besar adalah pada ibu yang berusia antara 20-35 tahun $(60 \%)$, paritas 1 dan $\geq 4$ (75\%), LILA $\leq 23,5 \mathrm{~cm}(55 \%)$, kadar haemoglobin $<11$ 9\% (70\%), tekanan darah $<140 / 90 \mathrm{mmHg}$ (65\%). Paritas, KEK, dan anemia berisiko terhadap BBLR sehingga perlunya mengadakan penyuluhan pada ibu hamil mengenai risiko BBLR dan dampak yang ditimbulkan akibat BBLR dan pemantauan status gizi ibu sebelum dan selama hamil perlu dilakukan sehingga kejadian BBLR dapat diturunkan terutama di Kabupaten Brebes $^{[4] .}$

Serta diharapkan dapat memberikan penyuluhan kepada pasangan usia subur (PUS) oleh petugas kesehatan agar proses kehamilan dan persalinan dapat direncanakan sehingga faktor risiko pada ibu hamil dapat dicegah

\section{Daftar Pustaka}

[1] Proverawati, Atikah. 2010. Berat Badan Lahir Rendah. Yogyakarta : Nuha Medika

[2] Manuaba, I.B.G. 2013. Ilmu Kebidanan, Penyakit Kandungan dan KB. Jakarta. Buku Kedokteran EGC

[3] Maryunani, Anik. 2013. Asuhan Bayi Dengan Berat Badan Lahir Rendah. Jakarta : TIM

[4] Wiknjosastro, Hanifa, dkk. 2009. Ilmu Kebidanan. Jakarta : PT Bina Pustaka

[5] Sulistyawati, Ari. 2012. Asuhan Kebidanan Pada Masa Kehamilan. Jakarta : Salemba Medika

[6] Pantiawati, Ika. 2010. Bayi dengan $B B L R$. Yogyakarta : Nuha Medika

[7] Muflihah, Siti, dkk. 2014. Biku Ajar Kehamilan. Jakarta : Salemba Medik 